\title{
PERFORMANCE MODELLING FOR MAINTENANCE OUTSOURCING PROVIDERS BASED ON THE KANO MODEL
}

\author{
Moses Laksono Singgih ${ }^{1}$, Primahasmi Dalulia ${ }^{2 *}$, Mokh. Suef $^{1}$, Putu Dana Karningsih ${ }^{1}$ \\ ${ }^{I}$ Department of Industrial Engineering, Institut Teknologi Sepuluh Nopember, Kampus ITS Keputih \\ Sukolilo, Surabaya 60111, Indonesia. \\ ${ }^{2}$ Department of Industrial Engineering, University of Merdeka Malang, Jalan Terusan Dieng No. 62- \\ 64, Malang 65146 Indonesia
}

(Received: April 2018 / Revised: April 2018 / Accepted: May 2018)

\begin{abstract}
Usually, maintenance activities are carried out by the maintenance department in a company, but now, some companies are outsourcing their maintenance activities. Outsourcing is the delegation of business functions to another company. The advantages of outsourcing include enabling a company to focus on its core business by outsourcing support activities, and changing fixed costs to variable costs. The aim of this research is to develop a multi-criteria performance measurement to assess the performance of maintenance outsourcing providers. Several previous studies have identified suitable performance criteria for maintenance outsourcing providers. However, those studies did not classify the criteria for achieving the desired level of performance. To address these shortcomings, this research has classified the criteria based on the Kano criteria. The criteria are: basic, one-dimensional, indifferent, reverse, and attractive. A managed case study analysis was performed at five Class B private hospitals in East Java to better understand the criteria in terms of the needs of a real hospital maintenance department. Previous research studies focused on understanding the relationship between each criterion and the associated level of performance, whereas the current research has focused instead on the relationship links between the criteria and the weighting of each criterion using DEMATEL-ANP. The outcome of this study is a simple instrument that can be directly used to evaluate the performance of maintenance outsourcing providers.
\end{abstract}

Keywords: Case study analysis; ICU; KANO; Medical devices; Outsourcing

\section{INTRODUCTION}

Maintenance activities can be categorised into corrective and preventive. The term corrective maintenance refers to activities that are performed after a system breakdown (Nosoohi \& Hejazi, 2011). On the other hand, preventive maintenance, includes inspection and spare part replacement, and is performed before system breakdown. The goal of preventive maintenance is to improve on one or more criteria, such as reliability, availability, and maintenance cost. All maintenance activities usually are performed by an internal maintenance department. Nevertheless, it is now common to outsource the performance of these activities. Outsourcing is defined as delegating a business function to other companies (Gomez et al., 2009). The Intensive Care Unit (ICU) in a hospital is a department which has a high degree of uncertainty. Medical equipment in ICU requires high availability and reliability to ensure patient safety.

\footnotetext{
*Corresponding author's email: primahasmi.dalulia@unmer.ac.id, Tel. +62-812-32825057 Fax.+62-31-5939362 Permalink/DOI: https://doi.org/10.14716/ijtech.v9i4.1888
} 
Patient safety is a construct that implies behaviour that is intended to minimise the risk of harm to patients through both system effectiveness and individual performance, and is designed to avoid injuries to patients from the care that is intended to help them. Harm is an unintended physical injury resulting from or contributed to by medical care that requires additional monitoring, treatment, or hospitalisation, or that results in death (Albrecht, 2015). It is crucial that the maintenance service provider has a high enough performance level in order to achieve that goal. The aim of this study is to develop a performance measurement model to assess maintenance outsourcing providers. In the healthcare industry in Indonesia, the performance measurement of maintenance service providers has not been performed and there is no systematic method of performance measurement. Performance measurement of the maintenance service provider is important. If the maintenance service provider has a good level of performance, then the availability and reliability of the medical equipment can be maintained. If the performance or performance of the maintenance service provider is not measured and evaluated, then there is the possibility of the service providers not improving their performance. According to Jackson and Pascual (2008) in Cruz and Rincon (2012), research on maintenance service outsourcing focusing on the integration of provider maintenance selection, performance evaluation and measurement has not been performed. Cruz and Rincon (2012) conducted a themed mapping review on previous studies on outsourced maintenance in the healthcare industry area. These earlier studies are broadly divided into four categories, namely mathematical models, conceptual research, empirical research on maintenance outsourcing for medical equipment, and empirical research on maintenance outsourcing in other fields. Almeida (2005) conducted a study on maintenance contract issues related to decision-making. In making decisions, decision makers choose alternatives based on the main criteria of cost and performance. Cruz et al. (2013) conducted research on the performance criteria of the maintenance service providers. The object of this research is more specific, as it is about the maintenance of medical equipment.

\section{METHODS}

\subsection{Performance Measurement}

Performance measurement is defined as a quantitative indicator that can be used to measure a particular goal (Dewangan \& Godse, 2014; Yildiz \& Demirel, 2014). In hospital, the performance of the maintenance outsourcing providers is directly related to patient safety. So, the performance of the maintenance outsourcing providers should be managed. The first step is to gather suitable criteria to use in the measurement process.

\subsection{Criteria Development}

The initial criteria in this study were gathered from a review of the literature. Then, the list of criteria was grouped into similar criteria (Almeida, 2005; 2007). Service quality is defined as the degree of error that occurs when a repair has been carried out, the expected condition of the equipment, and average customer satisfaction (Almeida, 2005; Almeida, 2007; Singgih \& Dalulia, 2016). Therefore, service quality can be understood to have a comprehensive meaning, which refers to the level of customer satisfaction with the services of the maintenance outsourcing provider that can be identified by the degree of error when the maintenance activities have been carried out. The details of the criteria obtained from a review of the previous research has been illustrated in Table 1.

The next step after gathering the criteria from the literature was to choose what the suitable criteria are for the ICU hospitals in East Java. This was explored through a case study analysis (Wahjudi et al., 2016) that was conducted in 5 private hospitals, in which the head of the maintenance department in each hospital served as an expert in this research. 
Table 1 Criteria obtained from the literature study

\begin{tabular}{|c|c|c|}
\hline Author & Criteria & Definition \\
\hline \multirow{4}{*}{ Almeida (2005) } & Dependability & $\begin{array}{l}\text { Response time accomplishment specified in } \\
\text { contract document }\end{array}$ \\
\hline & Service Quality & $\begin{array}{l}\text { Degree of errors that occurs when a repair is } \\
\text { carried out }\end{array}$ \\
\hline & Cost & $\begin{array}{l}\text { Contract cost stated in the contract proposal over } \\
\text { a certain period }\end{array}$ \\
\hline & Response time & $\begin{array}{l}\text { Time required from maintenance service provider } \\
\text { called until the maintenance service provider } \\
\text { comes to repair. }\end{array}$ \\
\hline \multirow{5}{*}{ Almeida (2007) } & \multirow{3}{*}{ Delivery time } & Time required for repair activities \\
\hline & & Time promised on contract document \\
\hline & & $\begin{array}{l}\text { Related with customer request, affected by } \\
\text { resource and affecting cost calculation }\end{array}$ \\
\hline & Cost & $\begin{array}{l}\text { Contract cost stated in the contract proposal over } \\
\text { a certain period }\end{array}$ \\
\hline & Dependability & $\begin{array}{l}\text { Response time achievement that has been stated } \\
\text { in contract document }\end{array}$ \\
\hline \multirow{14}{*}{ Liou \& Chuang (2010) } & Relationship & $\begin{array}{l}\text { Risk and reward sharing, airline and ground } \\
\text { service provider collaboration. }\end{array}$ \\
\hline & Flexibility & $\begin{array}{l}\text { Flexibility to handle abnormal condition, such as } \\
\text { flight delays, overbooking and incidents }\end{array}$ \\
\hline & Information sharing & $\begin{array}{l}\text { Computer system capability and information } \\
\text { sharing. }\end{array}$ \\
\hline & Knowledge skills & $\begin{array}{l}\text { Manpower knowledge of maintenance } \\
\text { outsourcing provider }\end{array}$ \\
\hline & Customer satisfaction & Average value of customer satisfaction \\
\hline & On time rate & Ratio equipment delivered or well done repairs. \\
\hline & Cost Saving & $\begin{array}{l}\text { Total cost of outsourcing activities less than the } \\
\text { costs stated in the contract proposal. }\end{array}$ \\
\hline & Flexibility in billing & Flexibility in payment condition. \\
\hline & Labor union & Outsourcing will affect on employee laid off. \\
\hline & Loss of management control & $\begin{array}{l}\text { Control functions of management when there is a } \\
\text { problem with the provider that resulted in airline } \\
\text { customer satisfaction. }\end{array}$ \\
\hline & Information security & $\begin{array}{l}\text { Security on information sharing between provider } \\
\text { and customer, related with long term reliance. }\end{array}$ \\
\hline & Response time & $\begin{array}{l}\text { Time required from maintenance service provider } \\
\text { called until maintenance service provider come to } \\
\text { repair. }\end{array}$ \\
\hline & Service Time & $\begin{array}{l}\text { Time required to perform repair or maintenance } \\
\text { activities. }\end{array}$ \\
\hline & Turn Around Time & $\begin{array}{l}\text { Total time begins from equipment stopping } \\
\text { operating until it is operating again. }\end{array}$ \\
\hline \multirow{4}{*}{ Cruz et al. (2013) } & $\begin{array}{l}\text { Firm Capacity \& Human } \\
\text { Resource }\end{array}$ & $\begin{array}{l}\text { Capability to fulfill maintenance contract } \\
\text { agreement. }\end{array}$ \\
\hline & Service Features & Service characteristic offered by provider. \\
\hline & Contractual Relationship & Contract types offered by provider. \\
\hline & Equipment Types & $\begin{array}{l}\text { The type of equipment which can be handled by } \\
\text { the service provider }\end{array}$ \\
\hline
\end{tabular}

A questionnaire was developed in order to determine the useful criteria from the experts using the Delphi method. The Delphi method is generally used to solicit opinions from participants who are considered competent in their field (Ciptomulyono, 2001). The Delphi method was 
defined as a structured method to guide interactive discussion groups and decision-making processes with the aim of facilitating brainstorming amongst a panel of experts to reach a consensus on a topic (Winkler et al., 2015). This method can be used as a means of exchanging information via brainstorming or through individual interactions in order to obtain an opinion from the group. The brainstorming approach in the Delphi method does not require any direct interaction between the participants. The steps to gather opinions in the Delphi method are as follows: (1) Organise a facilitation team that fully understands the topics; (2) Choose experts who will be involved in the discussion; (3) Provide information to the participants regarding the purpose of the discussion; (4) Distribute questionnaires to the experts regarding the proposed criteria and the determination of important weights; (5) Collect the questionnaires (administered by the moderator), structure the answers, and re-distribute the results to the experts; (6) Create a new questionnaire that includes the list of criteria or objective chosen and the assigned weighting average, and ask each participant to evaluate or give feedback on the results; and (7) Repeat steps number 5 and 6 until consensus is obtained.

\subsection{Kano Model}

The Kano model classifies the features of products into five categories, namely: must be, onedimensional, indifference' and reverse, and attractive (Basfirinci \& Mitra, 2015; Suef et al., 2017). Attributes that are classified 'must be' are defined as the basic attributes of service quality that are related to customer satisfaction. These basic features are essential for every consumer. If the basic features cannot be fulfilled, then it will lead to consumer dissatisfaction. For example, the equipment must function normally. A classification of indifference is applied to attributes that do not affect the level of satisfaction of the consumer, whereas a reverse classification is applied to attributes that lead to consumer dissatisfaction. The Kano model was used because the principles of the basic and special requirements can be identified in detail (Suzianti et al., 2015) In addition to the criteria defined as the basic and special requirements, the principles of Kano can also identify any non-essential criteria that can be removed without affecting the consumer perception of the product or service. In this study, the desired outcome of the case study analysis was to determine what basic and additional criteria are needed. The Kano principles are used to select the attributes or criteria that constitute the basic and additional features of the maintenance service provider. Criteria that do not affect the outcome will be eliminated from the list of criteria that influence the performance of the maintenance service provider. The following steps were performed when implementing the Kano model: (1) Identify the product or services requirement; (2) Develop the Kano questionnaire; and (3) Plot the Kano matrix by calculating the extent of satisfaction and dissatisfaction using Equations 1 and 2. (Hartono et al., 2017 ; Hartono, 2016)

$$
\begin{aligned}
\text { Extent of satisfaction } & =\frac{A+O}{A+O+M+I} \\
\text { Extent of dissatisfaction } & =\frac{O+M}{(A+O+M+I) \times(-1)}
\end{aligned}
$$

Where $\mathrm{A}$ is the attractive criteria; $\mathrm{O}$ is the one-dimensional criteria; $\mathrm{M}$ is the must be criteria; and $\mathrm{I}$ is the indifference criteria

\subsection{DEMATEL - ANP Integration}

DEMATEL is a method that can be used to determine the links between various criteria. In addition to being able to capture the pattern of links between the criteria, the DEMATEL method is also able to capture and analyse the dominant criteria in a particular system (Yoserizal \& Singgih, 2012). In Lee et al. (2011), an integration of the DEMATEL and ANP methods was used to analyse the corresponding relationships between the factors. If the relationships between the factors affecting an investment are known, the decision-making 
process is expected to be more effective and efficient. The DEMATEL method can be used to investigate the relationship between the factors of a stock investment, followed by use of the ANP to evaluate the magnitude and links between the factors. The DEMATEL method is often applied to effectively arrange problems that contain links between the factors. The steps for implementing DEMATEL are as follows: (1) Construct an evaluation scale; (2) Develop the direct relationship matrix; (3) Develop the normalisation matrix; (4) Construct the total relationship matrix; (5) Calculate the importance and relationship values; and (6) Develop the network relationship matrix (NRM). ANP is designed to accommodate relationship and interdependence criteria, and can complement weaknesses in the Analytical Hierarchy Process (AHP). ANP can be seen as a generalisation of AHP. The fundamental difference between AHP and ANP is that the ANP is used in multi-criteria decision-making and is focused on the corresponding relationships between the criteria. AHP assumes that there is no link between the criteria and only explores hierarchical relationships. The ANP is able to represent the level of interest of various parties while taking into account the interdependence of any existing criteria and sub-criteria. A weighting calculation using the ANP can be performed using the Super Decision software package. The integration of the research methods can be illustrated in Figure 1 .

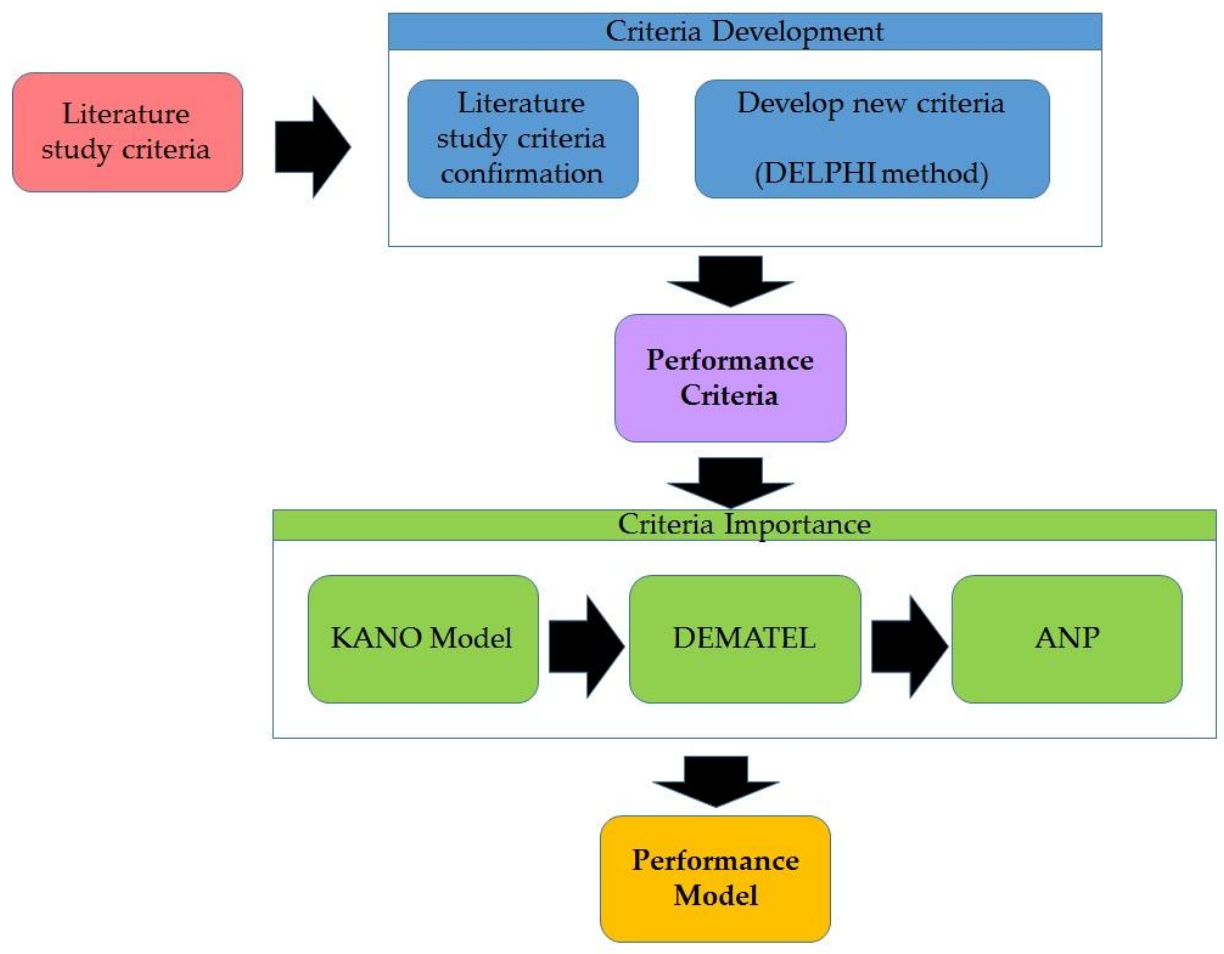

Figure 1 Method integration

\subsection{Research Position}

This study includes the concept of outsourcing maintenance activities and then monitoring selected performance measures using the criteria used in each phase of the outsourcing process. The resulting model can be used by the hospital when considering how best to measure the performance of outsourced maintenance functions. The idea of the study was obtained from the previous studies managed by Dewangan and Godse (2014) regarding their mapping review of research on outsourcing the maintenance of medical equipment. The healthcare industry is a service industry that is closely related to patient safety, and the characteristics of this industry are unique when compared to the manufacturing industry. In Indonesia, the performance measurement of outsourced maintenance activities is generally not managed by the hospital. 
The performance criteria were obtained from a study with several references (Almeida, 2005; Almeida, 2007; Lee et al., 2011; Yildiz \& Demirel, 2014, Singgih and Dalulia (2016)). However, Yildiz and Demirel, (2014) focused their research on the correlation of each criterion against the delivery of the service, and there was no stated preference level of interest in the form of the weighting of those criteria. The development of criteria can be managed by the method of case study analysis, which performs the collection, comparison and confirmation of the criteria used and is considered important by the users of outsourced maintenance. Case study analysis was used by (Angkiriwang, et al., 2014) by comparing the type of uncertainty in the demand characteristics of four different companies. The present study adopted the method of case study analysis to confirm the performance criteria of the new maintenance outsourcing providers obtained from the literature. The case study analysis was conducted in five class B hospitals in East Java. This study required the participation of the decision makers, or experts, in the field of maintenance at each hospital. These experts were asked to provide an assessment or to act as a resource throughout the study. The importance of the criteria that were obtained from literature was determined by each user. The criteria that were considered to be important to the users were then compared and selected using the principles of the Kano method, which separated the criteria into basic and additional attributes, and then weighted them against each criterion. There were some weighting methods proposed in the previous studies, including the Multi Attribute Utility Theory (MAUT) proposed by Almeida (2005) and Almeida (2007). Other weighting methods include an integration between the DEMATEL and ANP methods proposed by Wahjudi et al. (2016) and Liou and Chuang (2010), where these methods were used to consider the relationship between the criteria in contrast to the MAUT method, which does not consider the linkages between the criteria. Consequently, the method resulting from the integration of DEMATEL and ANP methods was used in the current study. Once the weighting criteria were obtained, a simple instrument was created that provided the maintenance performance measures in the form of a list of criteria and weights.

\section{RESULTS AND DISCUSSION}

The criteria that were selected from the literature were defined as the initial criteria. The criteria selected from the literature is shown in Table 1. The list of criteria included in the previous research has been consolidated by combining criteria with similar meanings. The results of this elaboration have been illustrated in Table 2.

Table 2 Literature study criteria

\begin{tabular}{|c|c|}
\hline Criteria & Definition \\
\hline Dependability & $\begin{array}{l}\text { Response time achievement that has been stated in contract } \\
\text { document. }\end{array}$ \\
\hline Flexibility & Flexibility in handling abonormal conditions. \\
\hline Service Quality & Customer satisfaction level due to provider services \\
\hline Cost & $\begin{array}{l}\text { Total cost that occurs from outsourcing activities in a certain } \\
\text { period. }\end{array}$ \\
\hline Turn Around Time & $\begin{array}{l}\text { Total time required by the maintenance service provider begins } \\
\text { with the request call until the equipment performed normally. }\end{array}$ \\
\hline Contractual Relationship & Contract types offered by the provider. \\
\hline Flexibility in billing & Flexibility in payment condition. \\
\hline Knowledge sharing & $\begin{array}{l}\text { Provider and customer relationship related to information and } \\
\text { knowledge. }\end{array}$ \\
\hline Equipment Types & Equipment types that the provider is capable of handling. \\
\hline $\begin{array}{l}\text { Firm Capacity \& Human } \\
\text { Resource }\end{array}$ & Provider capability on fulfill maintenace contract agreement. \\
\hline
\end{tabular}


The new criteria differed from one expert to another. However, there were some criteria that different experts defined similarly. The process of selecting the new criteria was based on the results of the scoring average and median. The scoring method used by each expert provided an assessment rate of the level of interest in each criterion. If the average value obtained from the results of the assessment indicated a value that was higher than 7.5, then the criterion could be used. A value of 10 was assigned if the criteria were considered to be very important, while a value of 1 was assigned if the criteria were considered to be unimportant. The scoring results have been shown in Table 3.

Table 3 New criteria

\begin{tabular}{clccccccc}
\hline No & \multicolumn{1}{c}{ Criteria } & H I & H II & H III & H IV & H V & Average & Median \\
\hline 1 & Technician Skill & 10 & 8.5 & 9 & 10 & 8 & 9.1 & 9 \\
2 & Administration & 10 & 8 & 8 & 8 & 10 & 8.8 & 8 \\
3 & Diagnosis Accuracy & 10 & 8.5 & 9 & 10 & 8 & 9.1 & 9 \\
4 & Part Availability & 10 & 8 & 9 & 10 & 8 & 9 & 9 \\
5 & SOP Clarity & 10 & 8 & 8 & 10 & 9 & 9 & 9 \\
6 & Routine reporting & 10 & 9 & 8 & 8 & 9 & 8.8 & 9 \\
7 & Attitude & 8 & 8.5 & 7 & 8 & 8 & 7.9 & 8 \\
\hline
\end{tabular}

Based on the calculation of the average value of each user, the average value increased by more than 7.5, and the median value approached the average value of each criterion. This may imply that the user reached the level of agreement for the new criteria, and that the new criteria that have been captured may be used as performance criteria.

The criteria collected were used to construct the performance model. Before assigning suitable weights, the criteria were evaluated using the Kano Model and separated into the five dimensions mentioned previously. The criteria developed from the Kano model are illustrated in Table 4.

Table 4 Kano dimension

\begin{tabular}{ll}
\hline \multicolumn{1}{c}{ Criteria } & \multicolumn{1}{c}{ Dimension } \\
\hline Dependability & one dimensional \\
Flexibility & must be \\
Service Quality & one dimensional \\
Cost & attractive \\
Turn Around Time & indifferent \\
Contractual Relationship & indifferent \\
Flexibility in billing & indifferent \\
Knowledge sharing & one dimensional \\
Equipment Types & must be \\
Firm Capacity & one dimensional \\
Technician Skill & one dimensional \\
Adminstration & one dimensional \\
Diagnosis Accuracy & one dimensional \\
Part Availability & attractive \\
SOP Clarity & one dimensional \\
Routine Reporting & attractive \\
Attitude & one dimensional \\
\hline
\end{tabular}

The indifferent criteria, such as the turn-around time, flexibility in billing, and contractual relationship, should be eliminated because they have no impact on performance. The gathered 
criteria should be weighted based on the importance definition by integrating the results from DEMATEL and ANP. The significance matrix is illustrated in Table 5.

Table 5 Significance matrix

\begin{tabular}{|c|c|c|c|c|c|c|c|c|c|c|c|c|c|c|}
\hline & $\mathrm{C} 1$ & $\mathrm{C} 2$ & C3 & C4 & C5 & C6 & C7 & C8 & C9 & C10 & C11 & $\mathrm{C} 12$ & C13 & C14 \\
\hline $\mathrm{C} 1$ & & 2.015 & 2.013 & & 2.013 & & 2.013 & 2.013 & 2.004 & 2.015 & 2.009 & & 2.009 & 2.009 \\
\hline $\mathrm{C} 2$ & & & 2.034 & & 2.034 & & 2.034 & 2.034 & 2.025 & 2.036 & 2.030 & & 2.030 & 2.030 \\
\hline $\mathrm{C} 3$ & & 2.039 & & & 2.038 & & 2.038 & 2.038 & 2.028 & 2.039 & 2.034 & & 2.034 & 2.034 \\
\hline $\mathrm{C} 4$ & & 2.085 & 2.083 & & 2.083 & 1.992 & 2.083 & 2.083 & 2.093 & 2.085 & 2.080 & 1.976 & 2.080 & 2.080 \\
\hline C5 & & 2.030 & 2.028 & & & & 2.028 & 2.028 & 2.038 & 2.030 & 2.043 & & 2.043 & 2.043 \\
\hline C6 & & & & & & & & & & & & & & \\
\hline C7 & & 2.099 & 2.097 & & 2.097 & 2.006 & 2.026 & 2.097 & 2.107 & 2.099 & 2.113 & 2.008 & 2.113 & 2.113 \\
\hline CS & & 2.065 & 2.063 & & 2.063 & & 2.063 & 1.992 & 2.073 & 2.065 & 2.079 & & 2.079 & 2.079 \\
\hline C9 & & 2.082 & 2.080 & & 2.080 & 1.990 & 2.080 & 2.080 & 2.011 & 2.082 & 2.095 & & 2.095 & 2.095 \\
\hline $\mathrm{C} 10$ & & 2.096 & 2.094 & & 2.094 & 2.003 & 2.094 & 2.094 & 2.104 & 2.023 & 2.109 & 1.986 & 2.109 & 2.109 \\
\hline C11 & & 2.113 & 2.112 & & 2.112 & 2.037 & 2.112 & 2.112 & 2.119 & 2.113 & 2.050 & 2.002 & 2.127 & 2.127 \\
\hline C12 & & 2.044 & 2.042 & & 2.042 & & 2.042 & 2.042 & 2.052 & 2.044 & 2.058 & & 2.058 & 2.058 \\
\hline C13 & & 2.017 & 2.015 & & 2.015 & & 2.015 & 2.015 & 2.025 & 2.017 & 2.030 & & & 2.030 \\
\hline C14 & & 2.016 & 2.014 & & 2.014 & & 2.014 & 2.014 & 2.024 & 2.016 & 2.030 & & 2.030 & \\
\hline
\end{tabular}

As the significance matrix has been defined, the ANP operation can be performed using the Super Decision software. The significance matrix is used in the development of the criteria relationship model, and the output of the ANP operation is the weight of each criterion. The criteria weights are illustrated in Table 6.

Table 6 Criteria description and weighting

\begin{tabular}{|c|c|c|c|c|}
\hline Notation & Criteria & Definition & Description & Weight \\
\hline $\mathrm{C} 1$ & Dependability & $\begin{array}{l}\text { Response time } \\
\text { achievement that has } \\
\text { been stated in contract } \\
\text { document. }\end{array}$ & $\begin{array}{l}\text { When the damage occurs and the } \\
\text { provider immediately responds in a short } \\
\text { time to deal with the damage, the } \\
\text { provider has a good performance and the } \\
\text { equipment can be immediately available } \\
\text { when needed by patients. }\end{array}$ & 0.0 \\
\hline $\mathrm{C} 2$ & Flexibility & $\begin{array}{l}\text { Flexibility in handling } \\
\text { abonormal conditions. }\end{array}$ & $\begin{array}{l}\text { Flexibility is a support level of } \\
\text { availability criteria. The availability level } \\
\text { of medical equipment can affect patient } \\
\text { safety. }\end{array}$ & 0.175684 \\
\hline $\mathrm{C} 3$ & Service Quality & $\begin{array}{l}\text { Customer satisfaction } \\
\text { level due to provider } \\
\text { services. }\end{array}$ & $\begin{array}{l}\text { Service quality is measured from the } \\
\text { error rate of damage handling. If the } \\
\text { provider handling the damage is not } \\
\text { appropriate, when the equipment is } \\
\text { needed by the patient, then the } \\
\text { equipment cannot function properly, } \\
\text { influencing patient safety. }\end{array}$ & 0.053293 \\
\hline $\mathrm{C} 4$ & Cost & $\begin{array}{l}\text { Total cost that occurs } \\
\text { from outsourcing } \\
\text { activities in a certain } \\
\text { period. }\end{array}$ & $\begin{array}{l}\text { If the total cost of using the provider is } \\
\text { low, the hospital may immediately call } \\
\text { the provider if there is damage to } \\
\text { medical equipment, so the availability of } \\
\text { the medical equipment is maintained. }\end{array}$ & 0.0 \\
\hline C5 & $\begin{array}{l}\text { Knowledge } \\
\text { sharing }\end{array}$ & $\begin{array}{l}\text { Provider and customer } \\
\text { relationship related } \\
\text { with information and } \\
\text { knowledge. }\end{array}$ & $\begin{array}{l}\text { If the provider is transparent about } \\
\text { equipment damage information, when } \\
\text { others time minor damage occurs, the } \\
\text { hospital can handle it on their own, thus } \\
\text { reducing the Mean Time To Repair. } \\
\text { Reduced MTTR can reduce the waiting } \\
\text { time of patients who need the equipment. }\end{array}$ & 0.005496 \\
\hline C6 & Equipment & Equipment types that & More equipment that can be handled by & 0.018238 \\
\hline
\end{tabular}




\begin{tabular}{|c|c|c|c|c|}
\hline Notation & Criteria & Definition & Description & Weight \\
\hline & Types & $\begin{array}{l}\text { provider capable to } \\
\text { handle. }\end{array}$ & $\begin{array}{l}\text { provider is better. If there are some } \\
\text { devices that are damaged at once can be } \\
\text { repaired simultaneously by the same } \\
\text { provider. when medical equipment is } \\
\text { needed by the patient, the equipment is } \\
\text { available and reliable. }\end{array}$ & \\
\hline $\mathrm{C} 7$ & Firm Capacity & $\begin{array}{l}\text { Provider capability to } \\
\text { fulfill the maintenace } \\
\text { contract agreement. }\end{array}$ & $\begin{array}{l}\text { If the whole provider company has the } \\
\text { ability to handle medical equipment both } \\
\text { technically and in management, then the } \\
\text { medical equipment is certain to be } \\
\text { available and reliable when needed by } \\
\text { the patient. }\end{array}$ & 0.132503 \\
\hline $\mathrm{C} 8$ & $\begin{array}{l}\text { Technician } \\
\text { Skill }\end{array}$ & $\begin{array}{l}\text { Technician ability to } \\
\text { solve medical device } \\
\text { problems or damage. }\end{array}$ & $\begin{array}{l}\text { If the technician of the provider has the } \\
\text { good ability to handle medical } \\
\text { equipment, the medical equipment can } \\
\text { be used properly when needed by the } \\
\text { patient. }\end{array}$ & 0.256881 \\
\hline C9 & Administration & $\begin{array}{l}\text { Quality and } \\
\text { administration } \\
\text { accuracy performed by } \\
\text { maintenance service } \\
\text { provider. }\end{array}$ & $\begin{array}{l}\text { Providers with a good administrative } \\
\text { system with a simple bureaucracy can } \\
\text { cut the waiting time for medical } \\
\text { equipment repairs that affect the } \\
\text { availability of medical equipment. }\end{array}$ & 0.041585 \\
\hline $\mathrm{C} 10$ & $\begin{array}{l}\text { Diagnosis } \\
\text { Accuracy }\end{array}$ & $\begin{array}{l}\text { Provider ability to } \\
\text { diagnose problems on } \\
\text { the medical devices, as } \\
\text { well as provide } \\
\text { diagnosis-related } \\
\text { information to users of } \\
\text { the service } \\
\text { maintenance service } \\
\text { provider. }\end{array}$ & $\begin{array}{l}\text { The accuracy of diagnosis is a criterion } \\
\text { for reliability and availability, so an } \\
\text { accuate diagnosis can lead to better } \\
\text { reliability and availability. }\end{array}$ & 0.222181 \\
\hline $\mathrm{C} 11$ & $\begin{array}{l}\text { Part } \\
\text { Availability }\end{array}$ & $\begin{array}{l}\text { Availability of } \\
\text { damaged parts } \\
\text { replacement. }\end{array}$ & $\begin{array}{l}\text { Replacement parts for the medical } \\
\text { equipment should be available because it } \\
\text { will shorten the repair time, so the } \\
\text { availability of medical equipment is } \\
\text { maintained }\end{array}$ & 0.01998 \\
\hline $\mathrm{C} 12$ & SOP Clarity & $\begin{array}{l}\text { Clarity of standard } \\
\text { operating procedures in } \\
\text { performing } \\
\text { maintenance activities } \\
\text { and transparency to } \\
\text { users. }\end{array}$ & $\begin{array}{l}\text { Providers who have SPO clarity can } \\
\text { perform medical equipment repairs } \\
\text { properly, effective and efficient. When } \\
\text { medical equipment is needed, the } \\
\text { medical equipment is available. }\end{array}$ & 0.00914 \\
\hline $\mathrm{C} 13$ & $\begin{array}{l}\text { Routine } \\
\text { Reporting }\end{array}$ & $\begin{array}{l}\text { Report providing after } \\
\text { maintenance activities. }\end{array}$ & $\begin{array}{l}\text { In addition to reporting after the } \\
\text { completion of medical equipment repair } \\
\text { activities, consumers generally expect } \\
\text { routine reporting over a period of time. } \\
\text { This is so then the medical equipment } \\
\text { maintenance activities can be well } \\
\text { documented as an experience for further } \\
\text { improvement. }\end{array}$ & 0.045708 \\
\hline $\mathrm{C} 14$ & Attitude & $\begin{array}{l}\text { Attitude of } \\
\text { maintenance service } \\
\text { provider. }\end{array}$ & $\begin{array}{l}\text { Attitude of human resources at the } \\
\text { provider end may affect the performance } \\
\text { of the provider. Good attitude from } \\
\text { providers is proven by technicians who } \\
\text { work well to improve the medical } \\
\text { equipment, so the availability and } \\
\text { reliability of equipment is also good. }\end{array}$ & 0.019312 \\
\hline
\end{tabular}


The flexibility criterion in the must-be category had the third highest weighting among the 14 proposed criteria. The first and second rank criteria, namely technician skill and diagnostic accuracy, were the criteria proposed by expert 1 according to the weighting assigned by expert 1. The criterion for technician skill, which was proposed by some experts as a new criterion, was considered to be a uniform criterion, the highest weight of which was considered to be a representation of the real conditions in the field. The criteria of cost and dependability did not contribute to the performance assessment. In addition, the cost criterion was not preferred because it was not a major consideration as it was unlikely to change due to the fact that it is a quantity that has precise numbers. Frequently, cost is correlated with the quality of the available facilities. In medical equipment, quality is important because it is related to the safety of the patient, but cost is not the emphasis. The criterion of dependability was not considered to be an important criterion when compared to flexibility. Therefore, in the pair-wise comparison of ANP, the rate of the criterion of flexibility was 9, which means that it was more important than the criterion of dependability.

\section{CONCLUSION}

By integrating several methods, namely case study analysis, Delphi, Kano, DEMATEL, and ANP, a performance model was developed which can be used by the healthcare industry to assess the performance of their maintenance outsourcing providers. The resulting performance criteria can be used as a reference when assessing the performance of general outsourcing. Case study analysis and Delphi was used to determine new criteria based on the needs of the user, Kano was used to identify criteria for the basic and special dimension requirements, DEMATEL was used to determine linkages between the criteria, and ANP was used to weight the criteria. The results obtained from the Kano method indicated that the criteria that must be fulfilled (basic requirements) must also provide flexibility in terms of abnormal situations and the type of equipment that can be handled by the provider (equipment types). The three criteria that had the highest weighting were the criterion of technician skill at 0.256881 , the criterion for diagnostic accuracy at 0.222181 , and the criterion of flexibility at 0.175684 . The two criteria that were assigned a weight of 0 (meaning that they did not contribute to performance) were the criteria of cost and dependability.

\section{ACKNOWLEDGEMENT}

This research can be completed because of funds from Kementerian Riset, Teknologi, dan Pendidikan Tinggi, with contract number: 010/SP2H/LT/DRPM/IV/2017.

\section{REFERENCES}

Albrecht, R.M., 2015. Patient Safety: The What, How, and When. The American Journal of Surgery, Volume 210(6), pp. 978-982

Almeida, A.T., 2005. Multicriteria Modelling of Repair Contract based on Utility and ELECTRE I Method with Dependability and Service Quality Criteria. Annals of Operations Research, Volume 138, pp. 113-126

Almeida, A.T., 2007. Multicriteria Decision Model for Outsourcing Contracts Selection based on Utility Function and ELECTRE Method. Computers \& Operation Research, Volume 34(12), pp. 3569-3574

Angkiriwang, R., Pujawan, I.N., Santosa, B., 2014. Managing Uncertainty through Supply Chain Flexibility: Reactive vs. Proactive Approaches. Production \& Manufacturing Research: An Open Access Journal, Volume 2(1), pp. 50-70 
Basfirinci, C., Mitra, A., 2015. A Cross Cultural Investigation of Airlines Service Quality through Integration of Servqual and the Kano Model. Journal of Air Transport Management, Volume 42, pp. 239-248

Ciptomulyono, U., 2001. Integrasi Metode Delphi dan Prosedur Analisis Hierarkhis (AHP) untuk Identifikasi dan Penetapan Prioritas Objektif/Kriteria Keputusan. Majalah IPTEK Jurnal Pengetahuan Alam dan Teknologi, ITS, Surabaya, Volume 12(1). pp. 42-52 (in Bahasa)

Cruz, A.M., Rincon, A.M.R., 2012. Medical Device Maintenance Outsourcing: Have Operation Management Research and Management Theories Forgotten the Medical Engineering Community? A Mapping Review. European Journal of Operational Research, Volume 221(1), pp. 186-197

Cruz, A.M., Rincon, A.M.R., Haugan, G.L., 2013. Measuring the Performance of Maintenance Service Outsourcing. Biomedical Instrumentation and Technology, Volume 47(6), pp. $524-535$

Dewangan, V., Godse, M., 2014. Towards A Holistic Enterprise Innovation Performance Measurement System. Technovation, Volume 34, pp. 536-545

Gomez, J.F., Parra, C., González, V., Crespo, A., Moreu, P., 2009. Outsourcing Maintenance in Services Providers. Safety, Reliability and Risk Analysis: Theory, Methods and Applications, pp. 829-837

Hartono, M., Santoso, A., Prayogo, D.N., 2017. How Kansei Engineering, Kano And QFD can Improve Logistics Services. International Journal of Technology. Volume 8(6), pp.10701081

Hartono, M., 2016. The Extended Integrated Model of Kansei Engineering, Kano, and TRIZ Incorporating Cultural Differences into Services. International Journal of Technology. Volume 7(1), pp. 97-104

Lee, W.-S., Huang, A.Y., Chang, Y.-Y., Cheng, C.-M., 2011. Analysis of Decision Making Factors for Equity Investment by DEMATEL and Analytic Network Process. Expert Systems with Applications, Volume 38(7), pp. 8375-8383

Liou, J.J.H., Chuang, Y.-T., 2010. Developing a Hybrid Multi-criteria Model for Selection of Outsourcing Providers. Journal of Expert Systems with Applications, Volume 37(5), pp. 3755-3761

Nosoohi, I., Hejazi, S.R., 2011. A Multi-objective Approach to Simultaneous Determination of Spare Part Numbers and Preventive Replacement Times. Applied Mathematical Modelling, Volume 35(3), pp. 1157-1166

Singgih, M.L., Dalulia, P., 2016. Peformance Criteria Development of Maintenance Service Provider using Case Study Approach Analysis. In: $20162^{\text {nd }}$ International Conference of Industrial, Mechanical, Electrical, and Chemical Engineering (ICIMECE), Yogyakarta, 67 October, Indonesia

Suef, M., Suparno, S., Singgih, M.L., 2017. Categorizing Product Attributes Efficiently in QFD-Kano: A Case Analysis in Telecommunication. The TQM Journal, Volume 29(3), pp. $512-527$

Suzianti, A., Faradilla, N.D.P., Anjani, S. 2015. Customer Preference Analysis on Fashion Online Shops using the Kano Model and Conjoint Analysis. International Journal of Technology. Volume 6(5), pp.881-885

Wahjudi, D., Singgih, M.L., Suwignjo, P., Baihaqi, I., 2016. The Relationship between Organisational Culture and Firm Performance: An Empirical Study on Indonesian Manufacturing Firms. International Journal of Productivity and Quality Management, Volume 18(1), pp. 1-18 
Winkler, J., Kuklinski, C.P.J.-W., Moser, R., 2015. Decision Making in Emerging Markets: The Delphi Approach's Contribution to Coping with Uncertainty and Equivocality. Journal of Business Research, Volume 68(5), pp. 1118-1126

Yildiz, S., Demirel, Z.H., 2014. The Benefits, Risks and Effects on Performance of the Outsourcing: A Comparative Study of Seasonal and Permanent Hotels. Procedia - Social and Behavioral Sciences, Volume 109, pp. 514-521

Yoserizal, Y., Singgih, M.L., 2012. Integrasi Metode DEMATEL (Decision Making Trial And Evaluation Laboratory) dan ANP (Analytic Network Process) dalam Evaluasi Kinerja Supplier. In: Prosiding Seminar Nasional Manajemen Teknologi XV 